\title{
Role of IgE Immune Complexes in the Regulation of HIV-1 Replication and Increased Cell Death of Infected U1 Monocytes: Involvement of CD23/FcERII- Mediated Nitric Oxide and Cyclic AMP Pathways
}

\author{
Fateh Ouaaz,* Francis W. Ruscetti, ${ }^{\dagger}$ Bernard Dugas,* \\ Judy Mikovits, ${ }^{\ddagger}$ Henri Agut, $\$$ Patrice Debré,* and \\ M. Djavad Mossalayi* \\ *Molecular Immuno-hematology Group, CNRS URA625, and \\ §Virology Department, CNRS EP57, Pitié-Salpêtrière Hospital, Paris, France \\ ${ }^{\dagger}$ Laboratory of Leukocyte Biology and ${ }^{\ddagger}$ Biological Carcinogenesis and \\ Development Program, Program Resources/DynCorp, Incorporated, \\ NCI-Frederick Cancer Research and Development Center, Frederick, \\ Maryland, U.S.A.
}

\begin{abstract}
Background: IgE/anti-IgE immune complexes (IgE-IC) induce the release of multiple mediators from monocytes/macrophages and the monocytic cell line U937 following the ligation of the low-affinity $F_{c \varepsilon}$ receptors (FCERII/CD23). These effects are mediated through an accumulation of CAMP and the generation of L-arginine-dependent nitric oxide (NO). Since high IgE levels predict more rapid progression to acquired immunodeficiency syndrome, we attempted to define the effects of IgE-IC on human immunodeficiency virus (HIV) production in monocytes.

Materials and Methods: Two variants of HIV-1 chronically infected monocytic Ul cells were stimulated with IgE-IC and virus replication was quantified. NO and cAMP involvement was tested through the use of agonistic and antagonistic chemicals of these two pathways. Results: IgE-IC induced p24 production by U1 cells with low-level constitutive expression of HIV-1 mRNAs and extracellular HIV capsid protein p24 levels ( $\mathrm{Ul}^{\text {low }}$ ), upon
\end{abstract}

their pretreatment with interleukin 4 (IL-4) or IL-13. This effect was due to the crosslinking of $\mathrm{CD} 23$, as it was reversed by blocking the IgE binding site on CD23. The IgE-IC effect could also be mimicked by crosslinking of CD23 by a specific monoclonal antibody. p24 induction by IgE-IC was then shown to be due to CD23-mediated stimulation of CAMP, NO, and tumor necrosis factor $\alpha$ (TNF $\alpha$ ) generation. In another variant of Ul cells with $>1$ log higher constitutive production of p24. levels $\left(\mathrm{U} 1^{\text {high }}\right)$, IgE-IC addition dramatically decreased all cell functions tested and accelerated cell death. This phenomenon was reversed by blocking the nitric oxide generation.

Conclusions: These data point out a regulatory role of IgE-IC on HIV-l production in monocytic cells, through CD23-mediated stimulation of CAMP and NO pathways. IgE-IC can also stimulate increased cell death in high HIV producing cells through the NO pathway.

\section{INTRODUCTION}

It is now well established that in addition to $\mathrm{T}$ cells, monocytes/macrophages play a central role in the pathogenesis of acquired immunodefi-

Address correspondence and reprint requests to: $\mathrm{M}$. Djavad Mossalayi, Groupe d'Immuno-hématologie Moléculaire, CNRS URA625, Hôpital de la Pitié-Salpêtrière, 91, Bd de l'Hôpital, 75013 Paris, France. ciency syndrome (AIDS) (1-3). The recently described ability of both cell types to harbor microbiologically latent human immunodeficiency virus (HIV) (4-7), (where viral expression can be induced to produce infectious virus) as well as to maintain restricted chronic low level viral expression $(8,9)$, suggests a mechanism for viral persistence during the long asymptomatic period 
seen in AIDS. Even in the lymph nodes, where virus is continually produced $(7,10)$, most $\mathrm{T}$ cells and macrophages containing provirus do not have detectable viral mRNA (7). It is clear that the macrophage serves as a viral reservoir, since HIV has been detected in tissue macrophages of many organs.

It is interesting that Con A-activated T cells can reactivate expression of latent virus in monocytes obtained from AIDS patients (6), suggesting that immune activation can play a role in HIV pathogenesis. In various human immune responses, IgE levels increase and correlate with an enhancement of in situ infiltration by hemopoietic effector cells and the release of multiple mediators from these cells (11-17). Allergy and IgE levels are not dramatically elevated in HIV patients, but high IgE levels predict more rapid progression to AIDS (18-20).

IgE and antigen directly activate the secretion of various cytokines from mast cells following cross-linking of the high-affinity receptor, FCeRI $(12,13)$. IgE/antigen also induce the synthesis and the release of tumor necrosis factor $\alpha$ (TNF $\alpha$ ) and other mediators from the human mononuclear phagocytic cell lineage (14-17). These cells are potent effectors of inflammation through their capacity to secrete preformed and newly synthesized monokines, respiratory burst products, and arachidonate metabolites (21).

Although monocytes/macrophages are a main reservoir of HIV-1, the role of IgE on HIVinfected cells and AIDS pathogenesis remains unclear. Monocytes/macrophages have a restricted FceRI expression (22), but can easily bind IgE following expression of a specific isoform of the lowaffinity receptor $\mathrm{CD} 23 \mathrm{~b} / \mathrm{Fc} \varepsilon \mathrm{RII}$, undetected in mice $(17,23,24)$. Recently, we have shown that CD23b is a functional IgE receptor on normal human monocytes and U937 cells $(17,25)$. Ligation of CD23 by IgE/anti-IgE or specific monoclonal antibody $(\mathrm{mAb})$ induces various monocyte functions through two second messengers: CAMP and nitric oxide (NO) $(17,25,26)$. In the present study, we attempted to define the role of IgE-anti-IgE immune complexes (IgE-IC) on HIV production in monocytes using two variants of the HIV-1 chronically infected monocytic Ul cells (a clone of U937). Our data point to a regulatory role of IgE-IC on HIV production in monocytic cells, through CD23-mediated stimulation of cAMP and NO pathways. In addition, we suggest that IgE-IC can stimulate increased cell death in high HIV producing cells through the NO pathway.

\section{MATERIALS AND METHODS}

\section{Reagents}

Cells were grown in RPMI medium supplemented with L-glutamine, penicillin, streptomycin, and $10 \%$ fetal calf serum (FCS) (all from Gibco Laboratories, Grand Island, NY, U.S.A.). Culture medium, chemicals, and FCS were tested for the absence of direct effects on U1 cells (CD23 expression, TNF $\alpha$, and p24 expression as activation markers). Cultures were also supplemented with: TNF $\alpha$ and neutralizing anti-TNF $\alpha$ mAb (Genzyme, Paris, France); human IgE (Stallergene, Paris, France); goat anti-human-IgE (Nordic Immunology, Tilburg, The Netherlands); $N^{\mathrm{G}}$ monomethyl-L-arginine (L-NMMA), D-NMMA, Larginine, D-arginine, superoxide dismutase (SOD), and catalase (all from Sigma, St. Louis, MO, U.S.A.); S-nitroso-acetyl-penicillamine (SNAP; Alexis Corporation, Läufelfingen, Switzerland); 6-morpholino-sydnonimine (SIN-1; Glaxo, Paris, France); FITC-conjugated CDI4-mAb, CD71-mAb, and $\mathrm{CD} 19-\mathrm{mAb}$ (clone BC3, IgG1 $\kappa$ ) (all from Immunotech, Marseille Lumigny, France). FITC-conjugated CD23-mAb (clone 25) was used for cell labeling and CD23-mAb (clone 135: IgGl $\kappa, F\left(\mathrm{ab}^{\prime}\right)^{2}$ or Fab) for biologic investigation (27). The mAb 135 have better specificity than mAb 25 in recognizing the IgE-binding site of CD23 (27) and, in its Fab form, to prevent CD23 cross-linking with no cell activation $(17,28)$.

\section{Cells}

U1 cells with low p24 production levels $\left(<250 \mathrm{pg} / 10^{5}\right.$ cells $/ \mathrm{ml}$ in 3 -day supernatants) designed later as $\mathrm{Ul}^{\text {low }}$ were a gift of T. Folks (CDC, Atlanta, GA, U.S.A.). They do not express CD23 $(<4 \%)$. Following $48 \mathrm{hr}$ of incubation at $37^{\circ} \mathrm{C}$ with $10 \mathrm{ng} / \mathrm{ml}$ of interleukin 4 (IL-4) or IL-13, the cells were collected, washed and analyzed for their reactivity with FITC-conjugated CD23-mAb. U1 ${ }^{\text {low }}$ cells became $>63 \% \mathrm{CD}^{2} 3^{+}$. In addition to $\mathrm{Ul}^{\text {low }}$ cells, we have also used a variant of Ul cells which raised spontaneously from long-term cultures of $\mathrm{U} 1^{\text {low }}$ cells, and stably express higher $(>1 \mathrm{log})$ surface density of CD23/ FceRII and CD14 compared with $\mathrm{Ul}^{\text {low }}$ cells. These cells express nonspecific esterases, and have 1 log higher extracellular p24 levels $\left(>2.5 \mathrm{ng} / \mathrm{ml} / 10^{5}\right.$ cells per 3 days) than $\mathrm{Ul}^{\text {low }}$ (see results). These cells are designated in this work as Ul ${ }^{\text {high }}$ cells. 


\section{Cell Cultures}

$\mathrm{U} \mathrm{l}^{\text {low }}$ or $\mathrm{U} \mathrm{l}^{\text {high }}$ cells were treated with IgE (1-10 $\mu \mathrm{g} / \mathrm{ml}$ ) for $\mathrm{l} \mathrm{hr}$, washed and incubated with anti-IgE $(1-30 \mu \mathrm{g} / \mathrm{ml})$ plus other factors, as indicated, for $48 \mathrm{hr}$. Other treatments were CD23$\mathrm{mAb}$ (clone 135) (27); an isotype-matched control (CD 19-mAb, $20 \mu \mathrm{g} / \mathrm{ml}$ ); and anti-FceRImAb (Clone 15-1, a gift from Dr. J. P. Kinet, National Institutes of Health, Bethesda, MD, U.S.A.) (29). In control experiments, this antiFceRI antibody induced the release of $23 \%$ histamine from human basophils. Some cultures were also supplemented with anti-human TNF $\alpha$ $\mathrm{mAb}(15 \mu \mathrm{g} / \mathrm{ml}) ;$ SOD $(120 \mathrm{U} / \mathrm{ml})$ and catalase ( $240 \mathrm{U} / \mathrm{ml})$; and chemical NO donors SIN-1 and SNAP. SOD and catalase used in this work inhibited $>80 \%$ superoxide levels induced by lipopolysaccharide (LPS) in human macrophages (data not shown). To some infected cultures, CD23-Fab $(20 \mu \mathrm{g} / \mathrm{ml})$, L-NMMA, and D-NMMA (1-1000 $\mu \mathrm{M})$ were added for $1 \mathrm{hr}$ before $\mathrm{IgE}$ treatment, washed; and afterwards incubated with the required above factors plus L-NMMA in D-NMMA for $48 \mathrm{hr}$. To reverse L-NMMA effect, the cultures were supplemented with L-arginine, compared with D-arginine. Preliminary analysis using various concentrations of these reagents (not shown) permitted definition of optimal doses used in the present work. Following 1-3 day of incubation, cell supernatants were collected and the levels of p24, nitrites, and TNF $\alpha$ were determined. Viable cells were counted through trypan blue exclusion.

\section{Factor Assays}

To assay virus replication levels, we have quantified the HIV capsid protein p24 by enzymelinked immunosorbent assay (ELISA; Institut Pasteur, Paris; or Dupont de Nemours, les Ulis, France) in cell supernatants, as recommended by the manufacturer. This test was yet reported to correlate with cell infection levels, in U1 cells in particular $(6,30)$. TNF $\alpha$ measurement was performed by ELISA (Genzyme, Cambridge, MA, U.S.A.). Stable end product of $\mathrm{NO}, \mathrm{NO}_{2}{ }^{-}$, was assayed using Greiss reaction modified as detailed elsewhere (31). Cell surface phenotype was assayed using immunofluorescence with FITC-conjugated mAb from Immunotech as previously described (25). Nonspecific butyrate esterase and its inhibition by sodium fluoride were performed as detailed elsewhere (25). Results were analyzed and compared using the Student $t$ test for paired data.

\section{HIV-1 mRNA Detection}

The experiments were performed as follows: $\mathrm{Ul}$ cells $\left(3 \times 10^{5} / \mathrm{ml}\right)$ were treated with $10 \mathrm{ng} / \mathrm{ml}$ IL- 4 or IL-13 for $48 \mathrm{hr}$, washed and treated with $\operatorname{IgE}(10 \mu \mathrm{g} / \mathrm{ml}) \mathrm{l}-\mathrm{hr}$ incubation followed by antiIgE $(30 \mu \mathrm{g} / \mathrm{ml})$ addition. After $48 \mathrm{hr}$, RNA was isolated using RNA-STAT (Tel-Test Inc., Freindswood, TX, U.S.A.). For reverse transcriptase-PCR (RT-PCR), amplification reactions of $1 \mu \mathrm{g}$ of RNA $(32,33)$ contained $2 \mathrm{mM} \mathrm{MgCl}, 10 \mathrm{mM}$ Tris- $\mathrm{HCl}$, $\mathrm{pH} 8.3,50 \mathrm{mM} \mathrm{KCl}, 1 \mathrm{mM}$ of each four deoxynucleotides (Perkin Elmer Cetus, Emerville, CA, U.S.A.). 100 units of M-MLV Reverse Transcriptase (BRL, Bethesda, MD, U.S.A.), 2.5 units AmpliTaq DNA polymerase, 1 unit RNase inhibitor (Promega), $0.01 \mathrm{M} \mathrm{DTT}$, and $1 \mu \mathrm{M}$ of each primer. Primer pairs used were: SK38/39 HIV gag (1543-1570, 1630-1657) (34); and GAPHD splice product $(371-388,546-565)$ (35). Thirty amplification cycles were carried out using a thermocycler (Perkin Elmer Cetus), denaturing at $94^{\circ} \mathrm{C}$ for $1 \mathrm{~min}$, annealing at $55^{\circ} \mathrm{C}$ for $1 \mathrm{~min}$, and extending at $72^{\circ} \mathrm{C}$ for $2 \mathrm{~min}$, followed by liquid hybridization as described (32). Probes used were SK19 HIV gag (1587-1627) and GAPDH (514-532). Analysis of hybridized products was visualized on a $8 \%$ nondenaturing acrylamide/IX TAE gel and exposure to Kodak XAR-5 film at $-50^{\circ} \mathrm{C}$ for $1-2 \mathrm{hr}$ (with intensifying screens). Amplification products were quantified on a densitometer (Molecular Dynamics, Sunnyvale, CA, U.S.A.) using the GPDH as a control.

\section{RESULTS}

\section{IgE-IC Enhances HIV Replication in IL-4- or IL-13-Treated U1 Cells}

The effect of IgE-IC on p24 production by U1 ${ }^{\text {low }}$ cells was assayed. Ul ${ }^{\text {low }}$ cells were also pretreated with IL-4 or IL-13 prior to incubation with IgE-IC. In fact, we have recently shown (17) that these cytokines are necessary to induce IgE responses in the monocyte/macrophage lineage, probably through the induction of FceRII (see below). As shown in Fig. 1, sequential treatment of Ul cells with IL-4 or IL-13 for $48 \mathrm{hr}$, then IgE-IC resulted in a significant induction of p24 levels $(p<0.003)$. Treatment with IL-4 or IgE-IC alone had no effect on p24 levels over three days of incubation, while IL-13 caused a suppression in p24 levels (Fig. 1B). To determine the role of IgE-IC on HIV-1 transcription, we 


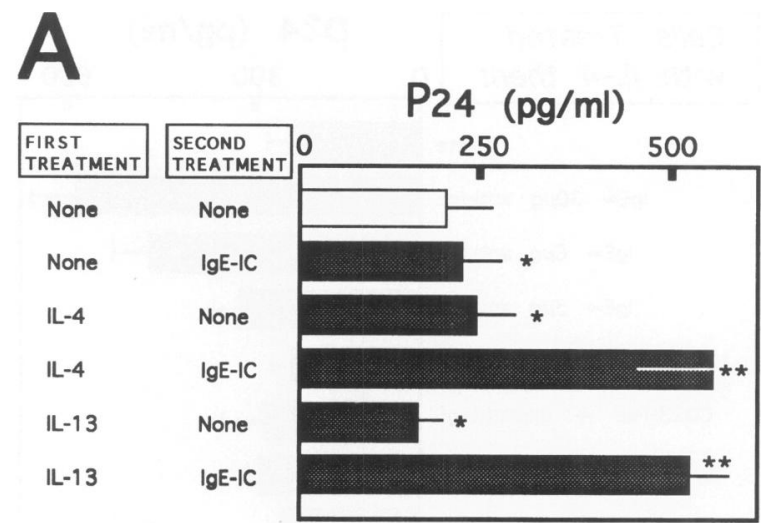

B

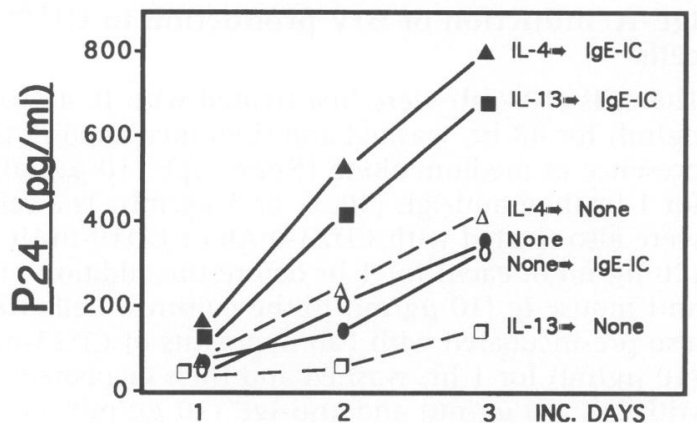

FIG. 1. Induction of p24 production in $\mathrm{Ul}^{\text {low }}$ cells by IgE-IC

The cells were incubated $\left(10^{5} / \mathrm{ml}\right)$ for $48 \mathrm{hr}$ in medium alone (None), or in the presence of IL-4 or IL-13 $(10 \mathrm{ng} / \mathrm{ml})$. After washing, they were incubated for $\mathrm{l} \mathrm{hr}$ with $\operatorname{IgE}(10 \mu \mathrm{g} / \mathrm{ml})$, washed, and reincubated for $48 \mathrm{hr}$ (A) or for 24,48 , or $72 \mathrm{hr}$ (B) with anti-IgE $(30 \mu \mathrm{g} / \mathrm{ml})$. Cell supernatants were then collected and their p24 quantified. Values are mean (B) or mean \pm SD from three distinct assays (A) done on three different Ul cell preparations.

have assayed the effect of IgE-IC on HIV-gag mRNA accumulation in Ul ${ }^{\text {low }}$ cells (Fig. 2). As shown, while IL-4 and IL-13 had no effect on basal gag levels, treatment with IgE-IC enhanced gag mRNA levels in $\mathrm{Ul}^{\text {low }}$ cells (2- to 4-fold amplification, as quantified by a densitometer). These results indicate that IgE-IC can augment HIV production in Ul cells.

\section{Requirement for FceRII/CD23 for IgE-Mediated Activation of U1 Cells}

Normal human monocytes express various potential ligands for IgE including FceRI, FceRII/
A
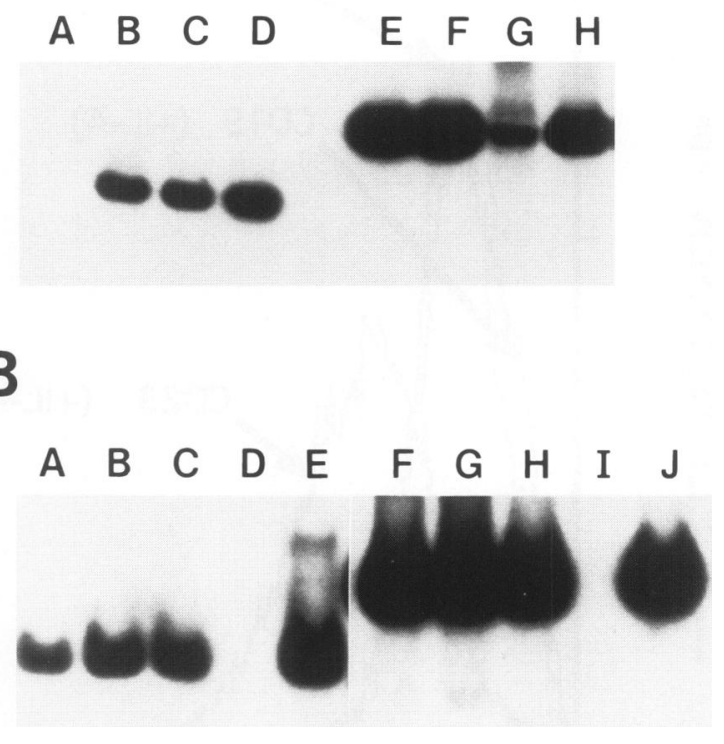

FIG. 2. Effect of IgE-IC on HIV mRNA accumulation in $\mathrm{Ul}^{\text {low }}$ cells

RNA from Ul cultured for $48 \mathrm{hr}$ was isolated and 1 $\mu \mathrm{g}$ of RNA was amplified as described in Materials and Methods. The oligomer hybridization autoradiography demonstrates the presence of amplified HIV-1 gag (Panel A, A-D; Panel B, A-E) and GAPDH-RNA (Panel A, E-H; Panel B, F-J). (A) Lane A, no RNA; Lane B, Ul; Lane C, Ul + IL-4; Lane D, Ul + IL-4/IgE-IC; Lane E, Ul; Lane F, Ul + IL-4; Lane G, Ul + IL-4/IgE-IC ( $1 \mu$ g anti-IgE); Lane H, $\mathrm{Ul}+\mathrm{IL}-4 / \operatorname{IgE}-\mathrm{IC}$ (2 $\mu \mathrm{g}$ anti-IgE). (B) Lane A, U1 + IL-13; Lane B, U1 + IL-13/IgE-IC; Lane C, $\mathrm{U} 1+\mathrm{IL}-13$ + IL-4/IgE-IC; Lane D, same as Lane C with no RT; Lane E, THP-1 productively infected with HIV; Lane F, Ul + IL-13; Lane G, Ul + IL-13/IgE-IC; Lane H, Ul + IL-13 + IL-4/IgE-IC; Lane I, same as Lane $\mathrm{H}$ with no RT; Lane J, THP-I productively infected with HIV.

CD23, Mac-2, Fc $\gamma$ RII, and Fc $\gamma$ RIII $(22,36-38)$. Having recently shown that IgE-IC trigger normal monocytes and U937 cell activation through the ligation of FceRII/CD23 $(17,25,26,39)$, we asked whether CD23 mediates IgE-induced p24 production by $\mathrm{Ul}^{\text {low }}$ cells, HIV-infected counterpart of U937 cells. The need for IL-4 or IL-13 for the induction of IgE-IC response is indicative of CD23 involvement as these cytokines are potent inducers of CD23 transcription and surface expression $(36,40)$ (Fig. 3). Ul ${ }^{\text {low }}$ cells, preincubated with IL-4, were thus treated with blocking Fab fragments of anti-CD23 mAb (CD23-Fab) $1 \mathrm{hr}$ before the addition of IgE-IC (Fig. 4). Pre- 


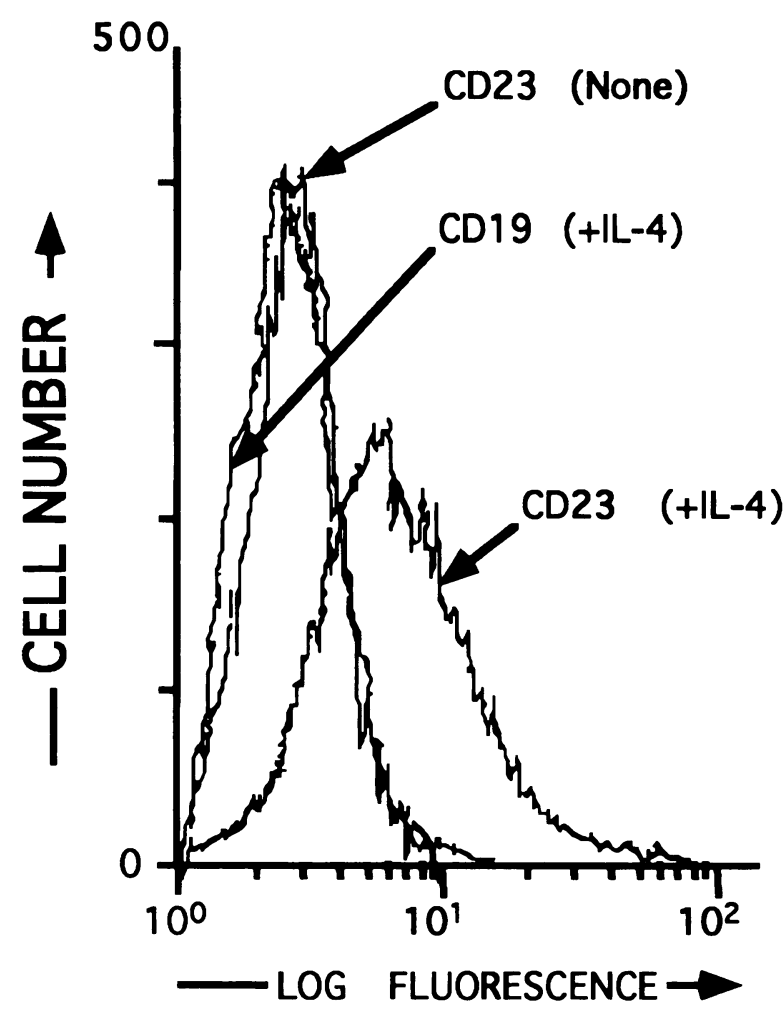

FIG. 3. Induction of $\mathrm{CD} 23$ expression on $\mathrm{Ul}^{\text {low }}$ cells by IL-4

Cells were incubated $\left(10^{5} / \mathrm{ml}\right)$ for $48 \mathrm{hr}$ in the presence of $10 \mathrm{ng} / \mathrm{ml} \mathrm{IL}-4$. They were then washed and assayed for their reactivity with FITC-CD23-mAb and isotype-matched control (FITC-CDI9-mAb).

treatment of Ul cells with CD23-Fab, and not an isotype matched $\mathrm{mAb}$ (CD 19-mAb), inhibits the effects of IgE-IC on p24 production by these cells. Furthermore, treatment of IL-4 induced Ul low cells with CD23-mAb + anti-mouse Ig (MIg) induces significant increases in p24 levels $(p<$ 0.02 ) (Fig. 4). Anti-MIg was used in order to induce the crosslinkage of surface CD23, necessary to obtain optimal monocyte activation. No such effect was observed with anti-MIg alone or with an isotype-matched control mAb (CDI9) (Fig. 4). In addition, we failed to detect FceR I on Ul cells, even after their activation by IL- 4 or IL-13, and anti-FceRI mAb failed to inhibit IgE-IC effects (data not shown). Finally, these culture conditions did not induce significant cell death and cell recovery was $>70 \%$ of control cultures pretreated with IL-4 alone. Together, these data indicate the involvement of FceRII/ CD23 in IgE-IC mediated induction of U $1^{\text {low }}$ cell activation and p24 production, while no role could be found for FceRI in the phenomenon.

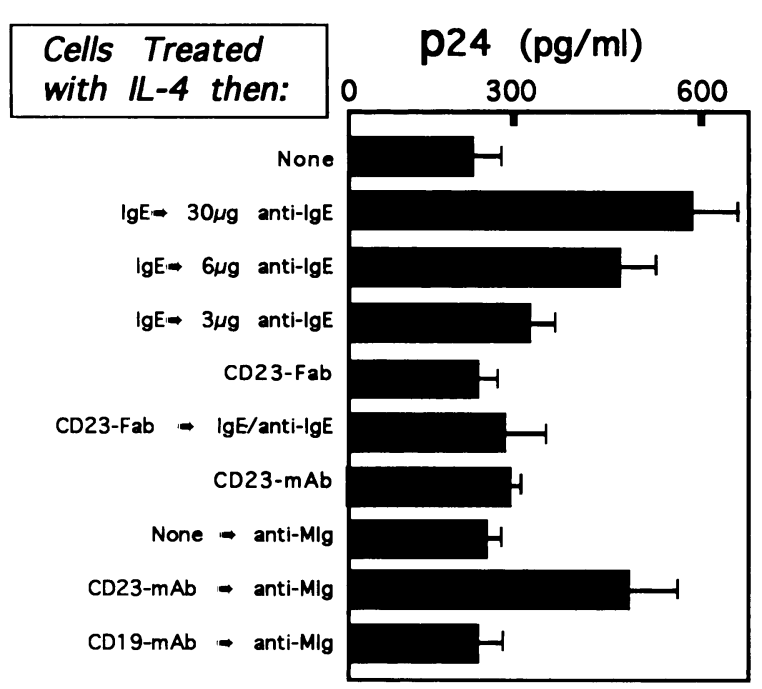

FIG. 4. Evidence for the role of CD23/FceRII in IgE-IC induction of HIV production in $\mathrm{Ul}^{\text {low }}$ cells

The cells $\left(10^{5} / \mathrm{ml}\right)$ were first treated with IL-4 (10 $\mathrm{ng} / \mathrm{ml}$ ) for $48 \mathrm{hr}$, washed and then incubated in the presence of medium alone (None), $\operatorname{IgE}(10 \mu \mathrm{g} / \mathrm{ml})$ for $\mathrm{l} \mathrm{hr}$ then anti-IgE $(30,6$, or $3 \mu \mathrm{g} / \mathrm{ml})$. The cells were also treated with CD23-mAb or CDI9-mAb $(20 \mu \mathrm{g} / \mathrm{ml}$ of each) for $1 \mathrm{hr}$ before the addition of anti-mouse Ig $(10 \mu \mathrm{g} / \mathrm{ml})$ to the cultures. Cells were also pre-incubated with Fab fragments of CD23-mAb $(10 \mu \mathrm{g} / \mathrm{ml})$ for $1 \mathrm{hr}$, washed and then incubated with $\operatorname{IgE}(10 \mu \mathrm{g} / \mathrm{ml})$ and anti-IgE $(30 \mu \mathrm{g} / \mathrm{ml})$. Cell supernatants were harvested following $48 \mathrm{hr}$ post IL-4 and the p24 quantified. Shown are mean \pm SD values of two distinct $U 1$ cell preparations, each done in duplicates.

\section{Involvement of CD23 Transduction Signals in IgE-IC-Mediated U $\mathrm{I}^{\text {low }}$ Cell Activation}

Ligation of CD23b by IgE-IC induces two major intracellular signals in monocytic lineage, cAMP and $\mathrm{NO}(17,25,26,28)$. The respective role of each of these intracellular events in IgE-dependent enhancement of $\mathrm{p} 24$ production in $\mathrm{Ul}^{\text {low }}$ cells was then assayed. Biochemical modulators of these factors were added to the cells prior to the treatment with IgE-IC. The inhibition of cAMP pathway by Rp-cAMP significantly reversed IgE-IC-dependent enhancement of p24 $(p<0.004)$ (Fig. 5A). Furthermore, addition of cAMP agonistic analogue (Dibut-cAMP) greatly enhanced the extracellular p24 levels in both untreated and IgE-IC-treated cells in a dose-dependent manner (Fig. 5B). Addition of the NO synthase inhibitor, L-NMMA also decreased IgE-IC induction of $\mathrm{p} 24$, but to a lesser extent than Rp-cAMP $(p<0.03)$. No such effects were 

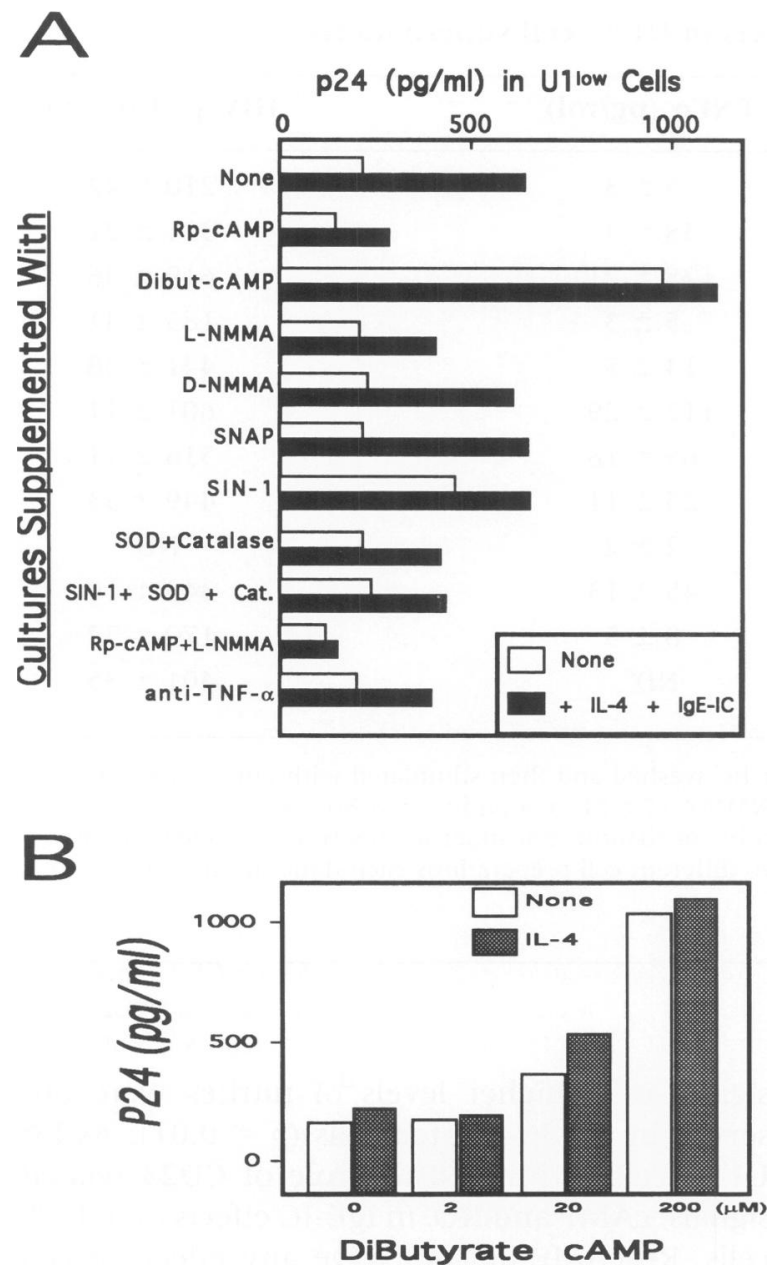

FIG. 5. Involvement of CD23-stimulated intracellular signaling in IgE-IC-mediated induction of HIV production in $\mathrm{U}^{\text {low }}$ cells

(A) IL-4-treated (as in Fig. 1) cells were supplemented $\left(10^{5} / \mathrm{ml}\right)$ with the following: $200 \mu \mathrm{M}$ RpcAMP, $100 \mu \mathrm{M}$ Dibut-cAMP, $1 \mathrm{mM}$ L-NMMA, $1 \mathrm{mM}$ D-NMMA, 1 mM SNAP, $200 \mu M$ SIN-1, SOD $(120 \mathrm{U} / \mathrm{ml})+$ catalase $(240 \mathrm{U} / \mathrm{ml})$, or $10 \mu \mathrm{g} / \mathrm{ml}$ antiTNF $\alpha$ mAb. Following 2 hr of incubation, the cells were washed and treated with IgE for $1 \mathrm{hr}$ then by anti-IgE and above factors as in Fig. 4. Cell supernatants were then assayed for their p24 content. Shown are mean values (SD $<17 \%$ ) from three different Ul cell preparations. (B) Ul ${ }^{\text {low }}$ cells were or were not treated with IL-4 for $48 \mathrm{hr}$, washed and then incubated for $48 \mathrm{hr}$ with decreasing concentrations of Dibut-cAMP. A dose-dependent induction of p24 is observed. Shown are mean values from two different experiments (SD $<13 \%)$.

observed with D-NMMA. The addition of the NO donor SNAP had little or no effect on p24 production by untreated $\mathrm{Ul}^{\text {low }}$ cells, while another NO donor compound, SIN-1, significantly increased $\mathrm{p} 24$ production by untreated $\mathrm{U} \mathrm{l}^{\text {low }}$ cells.
Neither compound had any effect on IgE-ICstimulated cells. In contrast to SNAP, SIN-1 also gives rise to peroxynitrites as well as to NO (41). Peroxynitrites are potent oxidants (42-44) and can be neutralized by anti-oxidant enzymes. We thus asked whether these oxidants play a role in IgE-IC effect on Ul ${ }^{\text {low }}$ cells. Cell treatment with SOD + catalase partially reversed IgE-IC mediated induction of p24 $(p<0.02)$, at levels close to those observed with L-NMMA (Fig. 5A). SOD + catalase also inhibits p24 enhancement by SIN-1 (Fig. 5A). The addition of both RpcAMP and L-NMMA completely reversed IgE-IC induced p24 production in $\mathrm{Ul}^{\text {low }}$ cells (Fig. 5A). In addition to p24 induction and as in U937 cells, $\mathrm{Ul}^{\text {low }}$ cell treatment with IgE-IC induces nitrites levels in the same cell supernatants (from $0.5 \pm$ $0.1 \mu \mathrm{M}$ in medium alone to $3.8 \pm 0.7 \mu \mathrm{M}$ with IgE-IC), completely reversed by L-NMMA treatment (data not shown). Altogether, these data suggest that cAMP accumulation and the formation of peroxynitrites (inhibited by both L-NMMA and anti-oxidants) play a role in p24 induction by IgE-IC.

\section{Involvement of TNF $\alpha$ in IgE-IC-Mediated Activation of HIV Production in U1 ${ }^{\text {low }}$ Cells}

CD23 has previously been shown to induce the production of TNF $\alpha$ in human monocytes $(17,39)$. We then asked the role of this cytokine in IgE-IC-mediated regulation of HIV expression. Anti-TNF $\alpha$ antibody decreased IgE-IC mediated p24 induction (Fig. 5A), which suggests a role of $\mathrm{TNF} \alpha$ in this phenomenon. The presence of TNF $\alpha$ is confirmed through the ability of IgE-IC to induce the production of TNF $\alpha$ from IL-4treated $\mathrm{Ul}^{\text {low }}$ cells (Table 1). TNF $\alpha$ increase by IgE-IC is correlated with p24 levels detected in the same supernatants (Table 1). TNF $\alpha$ production is inhibited by L-NMMA, and to lesser extent by Rp-cAMP, while D-NMMA addition had no effect on this phenomenon. L-NMMA effect was partially reversed through the addition of L-arginine but not D-arginine to IgE-IC-stimulated cultures. Addition of both Rp-cAMP and L-NMMA completely abolished TNF $\alpha$ induction by IgE-IC (Table 1). Together, these data demonstrate the involvement of CD23-related TNF $\alpha$ in IgE-IC activation of $\mathrm{Ul}^{\text {low }}$ cells. 
TABLE 1. IgE-mediated induction of TNF $\alpha$ and p24 levels in $\mathrm{Ul}^{\text {low }}$ cell supernatants

\begin{tabular}{lcc}
\hline Ul $^{\text {low }}$ Cells Cultured with: & TNF $\boldsymbol{\alpha}$ (pg/ml) & HIV-p24 (pg/ml) \\
\hline None $^{a}$ & $5 \pm 3$ & $210 \pm 42$ \\
IgE $(2 \mu \mathrm{g})$-Anti-IgE $(10 \mu \mathrm{g})$ & $38 \pm 4$ & $321 \pm 21$ \\
IgE $(10 \mu \mathrm{g})$-Anti-IgE $(10 \mu \mathrm{g})=(\mathrm{IgE}-\mathrm{IC})$ & $125 \pm 21$ & $619 \pm 36$ \\
L-NMMA & $5 \pm 3$ & $183 \pm 41$ \\
L-NMMA + IgE-IC & $14 \pm 5$ & $441 \pm 38$ \\
D-NMMA + IgE-IC & $112 \pm 29$ & $601 \pm 11$ \\
L-NMMA + L-arginine + IgE-IC & $65 \pm 18$ & $516 \pm 71$ \\
L-NMMA + D-arginine + IgE-IC & $25 \pm 11$ & $449 \pm 33$ \\
Rp-CAMP & $2 \pm 2$ & ND \\
Rp-CAMP + IgE-IC & $45 \pm 13$ & $349 \pm 10$ \\
Rp-CAMP + L-NMMA + IgE-IC & $8 \pm 5$ & $170 \pm 32$ \\
IgE-IC + anti-TNF $\alpha$ mAb & $\mathrm{ND}^{a}$ & $401 \pm 35$
\end{tabular}

IL-4-treated cells (as in Fig. 1) were incubated $\left(10^{5} / \mathrm{ml}\right)$ with IgE for $1 \mathrm{hr}$, washed and then stimulated with anti-IgE. Some cells were supplemented with anti-TNF $\alpha(10 \mu \mathrm{g} / \mathrm{ml}), \mathrm{L}-\mathrm{NMMA}(1 \mathrm{mM}), \mathrm{D}-\mathrm{NMMA}(1 \mathrm{mM})$, L-arginine $(5 \mathrm{mM}), \mathrm{D}$-arginine $(5 \mathrm{mM})$, or/and Rp-cAMP $(100 \mu \mathrm{M}) 1 \mathrm{hr}$ before IgE-IC treatment. Following $48 \mathrm{hr}$ incubation, cell supernatants were collected and assayed for their TNF $\alpha$ and p24 content. Values are mean \pm SD from two different cell preparations each done in duplicates.

${ }^{a} \mathrm{ND}=$ not determined.

\section{Effects of IgE-IC on U1 $\mathbf{l}^{\text {high }}$ Cells}

IgE-IC effects on Ul ${ }^{\text {low }}$ cells led us to assay their effect on another variant of Ul cells with high HIV production levels. As observed in activated normal human monocytes/macrophages (17) or differentiated U937 cells (25), these cells are stably $\mathrm{CD} 23^{+}, \mathrm{CD} 14^{\text {low }}$ (Table 2 ). They produce higher p24 (>2.5 ng/ml) and TNF $\alpha(>235 \mathrm{pg} /$ $\mathrm{ml}$ ) levels after IgE-IC incubation (Table 2 ) compared to $\mathrm{Ul}^{\text {low }}$ cells (Fig. 1 and Table 1). These cells were designated as $U{ }^{\text {high }}$ cells in this study. $\mathrm{U} 1^{\text {high }}$ cells expressed $\mathrm{CD} 23$ and did not require pretreatment with IL-4 to respond to IgE-IC or CD23-mAb + anti-MIg (Fig. 6). In contrast to $\mathrm{Ul}^{\text {low }}$ cells, 48 -hr $\mathrm{Ul}^{\text {high }}$ cell incubation with IgE-IC resulted in a significant decrease of p24 levels, correlating with decreases of the viable cell numbers recovered from these culture (Fig. 6).

The Role of Nitric Oxide in IgE-IC-Mediated Cytostasis of $\mathrm{Ul}^{\text {high }}$ Cells

Following treatment with IgE-IC, U1 $1^{\text {high }}$ cell death is preceded by a marked cytostasis as the cells displayed lower TNF $\alpha$ production and a dramatic decreases of surface CD23, CD14, and CD71 expression levels (Table 2). In contrast, significantly higher levels of nitrites were observed in IgE-IC-treated cells $(p<0.01)$. As for $\mathrm{U} 1^{\text {low }}$ cells, we asked the role of $\mathrm{CD} 23$-related signals, cAMP and NO, in IgE-IC effects on $\mathrm{U} 1^{\text {high }}$ cells. Rp-cAMP did not have any effect on cell death and growth arrest induced by IgE-IC and

TABLE 2. Cytostatic effect of IgE-IC on $\mathrm{U1}^{\text {high }}$ cells

\begin{tabular}{lcc}
\hline & None & +IgE-IC $^{a}$ \\
\hline Cell number/ml & $10 \times 10^{5}$ & $2 \times 10^{5}$ \\
HIV-p24 $(\mathrm{ng} / \mathrm{ml})$ & $3.1 \pm 0.3$ & $0.6 \pm 0.2$ \\
TNF- $\alpha(\mathrm{pg} / \mathrm{ml})$ & $300 \pm 21$ & $62 \pm 13$ \\
Nitrites $(\mu \mathrm{M})$ & $1.2 \pm 0.2$ & $4.3 \pm 0.7$ \\
& Mean fluorescence intensity \\
$\mathrm{CD}^{+} 3^{+}$ & 230 & 82 \\
$\mathrm{CD}^{+}$ & 112 & 41 \\
$\mathrm{CD}^{+}$ & 182 & 93
\end{tabular}

${ }^{a}$ Cells $\left(2 \times 10^{5} / \mathrm{ml}\right)$ treated with IgE $(10 \mu \mathrm{g})$ for $\mathrm{l} \mathrm{hr}$ then $48 \mathrm{hr}$ with anti-IgE $(10 \mu \mathrm{g})$. Cells were then collected, viable cells counted, and their surface CD23, CD14, and CD71 expression levels quantified by direct immunofluorescence. Cell supernatants were collected and assayed for their p24, $\mathrm{TNF} \alpha$, and nitrite content. Values are mean or mean \pm SD from two different $\mathrm{Ul}^{\text {high }}$ cell preparations. 


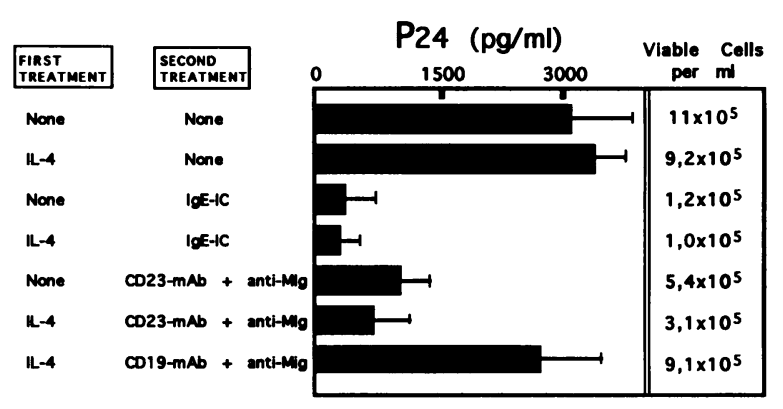

FIG. 6. Effects of IgE-IC and CD23-ligation on p24 levels and cell numbers in $U 1^{\text {high }}$ cells

The cells were preincubated for $48 \mathrm{hr}$ in medium alone or with IL-4 $(10 \mathrm{ng} / \mathrm{ml})$, then washed and postincubated $\left(2 \times 10^{5} / \mathrm{ml}\right)$ with $\operatorname{IgE}(10 \mu \mathrm{g} / \mathrm{ml})$ for $1 \mathrm{hr}$ before the addition of anti-IgE $(10 \mu \mathrm{g} / \mathrm{ml})$. Some IL-4-treated cells were also incubated with CD23-mAb or CD 19-mAb $(20 \mu \mathrm{g} / \mathrm{ml})$ for $1 \mathrm{hr}$ before the addition of anti-MIg $(10 \mu \mathrm{g} / \mathrm{ml})$. Following 48 hr, p24 levels and the number of cells were evaluated. Shown are mean \pm SD values from three distinct $U \mathrm{I}^{\text {high }}$ cell experiments.

further addition of Dibut-cAMP did not modify cell numbers (Fig. 7) but increased p24 levels (from $1.2 \pm 0.3$ to $2.4 \pm 0.5 \mathrm{ng} / \mathrm{ml}$ ). By contrast, the addition of L-NMMA or SOD + catalase nearly abolished the accelerated cell death stimulated by IgE-IC (Fig. 7). L-NMMA effect was reversed through the addition of L-arginine but not $\mathrm{D}$-arginine to the cultures (data not shown),

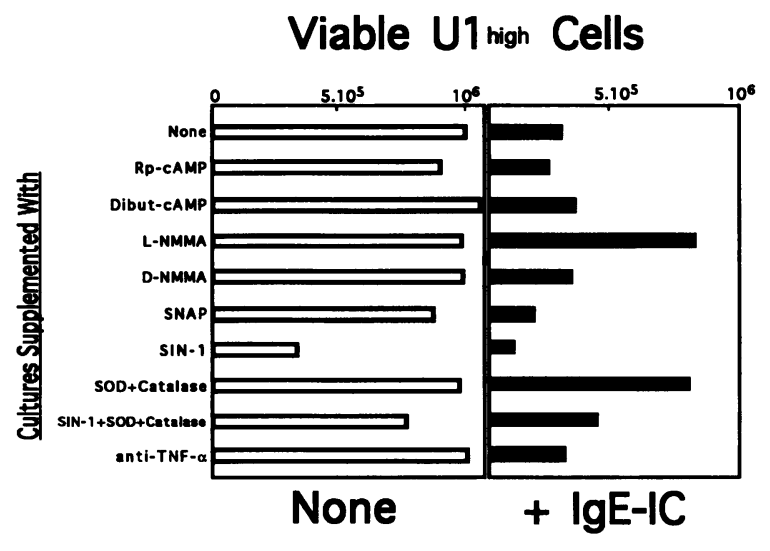

FIG. 7. Effects of cAMP and NO agonistic and antagonistic compounds on $\mathrm{Ul}^{\text {high }}$ cell proliferation

Cells were incubated in medium alone (None) or with IgE-IC and various compounds as in Fig. 5A. Mean from two different $\mathrm{Ul}^{\text {high }}$ cell cultures, each done in duplicates (SD $<18 \%$ ). Data suggest the role of peroxynitrites in IgE-mediated inhibition of Ul ${ }^{\text {high }}$ cell growth. and IgE-IC effect was not affected by D-NMMA. Furthermore, addition of SIN-1 dramatically decreased cell numbers in untreated $\mathrm{Ul}^{\text {high }}$ cells, while little or no effect was observed with SNAP. SIN-1 effect can partially be reversed by SOD + catalase (Fig. 7). Finally, the addition of neutralizing anti-TNF $\alpha$ had no effect on IgE-IC function (Fig. 7). Together, these data suggest a role of peroxynitrites in anti-proliferative and/or cell death induced by IgE-IC on $\mathrm{Ul}^{\text {high }}$ cells.

\section{DISCUSSION}

The present work demonstrated biphasic regulatory effects of IgE-IC on HIV replication and the cell growth and function of monocytic, chronically HIV-infected Ul cells. These IgE effects depended upon the activation state of these cells. In U $1^{\text {low }}$ cells with no CD23 or CD14 on the cell surface and low production of TNF $\alpha$ and HIV (Fig. 1 and Table 1), IgE-IC increased the production of HIV and the production of p24. This effect was dose dependent, and required the expression of $\mathrm{CD} 23$ on the surface of $\mathrm{Ul}^{\text {low }}$ cells (Fig. 4). CD23 expression could easily be obtained following cell treatment with various physiologic factors: IL-4, IL-13, GM-CSF, or IFN- $\gamma(25,36,40)$ (Fig. 3). We also assayed the effect of IgE-IC on a variant of Ul cells with high HIV transcription and p24 levels ( $\mathrm{Ul}^{\text {high }}$ ). These cells expressed CD23 without a need for IL-4, and their treatment with IgE-IC dramatically inhibited their functions, including proliferation; TNF $\alpha$, HIV, and p24 production; and the expression of CD14, CD71, and CD23 (Table 2). Preliminary analysis of the mechanism of accelerated U $I^{\text {high }}$ cell death by IgE-IC shows apoptosis, necrosis, or both. The reason for such differences is now under investigation. High doses of oxidants induce necrosis consistent with the suggestion of Duvall and Wyllia that the severity of the insult determines the form of cell death (45). NO has previously been implicated as an inducer of apoptosis in the monocyte/macrophage lineage (46).

Therefore, IgE-IC displays a potent proviral effect on infected monocytic Ul cells. It up-regulates viral production in U ${ }^{\text {low }}$ cells and stimulates the death of highly infected cells. However, similar studies on in vivo infected macrophages will permit further definition of IgE role on HIV pathogenesis. Our data, however, may explain the rapid progression to AIDS or bad prognosis of AIDS patients with high serum IgE levels (17- 
20). IgE could mediate induction of viral expression of latent HIV in infected macrophages (6), increasing patient viremia. Cell death and the liberation of HIV particles from activated macrophages may also contribute to the viral infection of adjacent cells.

Similar to normal human monocytes (17), ligation of CD23 seems to be required for IgEmediated Ul cell stimulation. This is evidenced through the ability of CD23-Fab fragments to block IgE-IC effects. In addition, cell stimulation was also observed following the ligation of CD23 by specific mAb. It is unlikely that FceRI accounted for IgE effects, as we failed to detect this receptor on these cells, and treatment with neutralizing anti-FceRI mAb was unable to reverse IgE mediated effects (data not shown). The use of isotype-matched control to CD23-mAb further supports that this phenomenon was not due to nonspecific Fc $\gamma$ R.

By contrast to most Fc receptors, CD23 does not belong to Ig super family, but is a member of animal c-type lectins, type II transmembrane glycoproteins (23). In addition to IgE binding site, CD23 was shown to display other functional domains, including a cytokine-like site, a lectin region, and a binding site for CD21 antigen $(23,27,47-49)$. Ligation of $b$ isoform of CD23 by IgE-IC or by appropriate mAb rapidly induces the accumulation of CAMP and the generation of nitric oxide in human monocytes (17), myelomonocytic precursors (25), eosinophils (50), and keratinocytes (28). Of interest, two other hematopoietic cell surface molecules, CD69 (51) and NKP-R1 (52), which belong to type II protein, c-type lectin family, were recently shown to mediate activation of nitric oxide pathway in human monocytes and rat natural killer cells respectively.

The role of CD23-linked transduction signals in the dichotomy of IgE-IC effects on Ul cells was then analyzed. On Ul ${ }^{\text {low }}$ cells, CD23-mediated HIV induction is due to both CAMP and NO pathways. The addition of cAMP antagonist (RpcAMP) reversed $62-79 \%$ of p24 levels induced by IgE-IC in U1 ${ }^{\text {low }}$ cells, while Dibut-cAMP produced a dose-dependent increase of p24 in U1 cells, regardless of their activation state $\left(\mathrm{U} 1^{\text {low }}\right.$ or $\mathrm{U}^{\text {high }}$ ). These data correlate with many reports which showed the pro-viral effects of cAMP and its induction in HIV pathogenesis (53-55).

The present work also points out the contribution of CD23-mediated NO pathway in p24 enhancement. The NO synthase inhibitor, L-NMMA, decreased by 20-39\% the IgE-IC-me- diated increases of p24 expression. This is likely due to peroxynitrites rather than NO itself, as chemical NO donor, SNAP, had little or no effect on $\mathrm{Ul}^{\text {low }}$ cells, while SIN-1, which donates both NO and peroxinitrites (41), had the capacity to increase by $34-52 \%$ p 24 levels produced by these cells. In contrast to $\mathrm{Ul}^{\text {low }}$ cells, our data indicate that NO is the major factor involved in the cytostatic effect of IgE-IC in Ul ${ }^{\text {high }}$ cells. This IgE-IC effect is completely abolished through cell treatment by L-NMMA or SOD + catalase, while the addition of SIN-1 further accelerated cell death. The effects of NO on U ${ }^{\text {high }}$ cells are thus likely related to the generation of peroxinitrites. Comparative levels of nitrites detected in $\mathrm{Ul}^{\text {low }}$ and $\mathrm{Ul}^{\text {high }}$ cell supernatants suggested that $\mathrm{Ul}^{\text {high }}$ cells became sensitive to apoptotic effect of peroxynitrites, compared with $\mathrm{Ul}^{\text {low }}$ cells. This may be due to the failure of these cells to generate enough antioxidants, due to their high degree of infection or to their differentiation fate. In this phenomenon, no effect of cAMP modulators was observed, and the addition of cAMP to $\mathrm{Ul}^{\text {high }}$ cells even increased $\mathrm{p} 24$ levels in a dosedependent manner without affecting their survival.

Therefore, while NO has an anti-viral action on other viruses (56-58), it seems to be a stimulatory pathway for HIV infection and thus may contribute to HIV pathogenesis. HIV products may be induced by peroxynitrites directly (as potent oxygen radicals) (59) or indirectly through their ability to induce TNF $\alpha$ production by these cells (Fig. 5). The similarity between p24 inhibition by L-NMMA and by anti-TNF $\alpha$ is in favor of the role of this cytokine in this IgE-IC effect. Nitrogen radicals and TNF $\alpha$ are potent inducers of the transcription factor $\mathrm{NF} \kappa \mathrm{B}$ in various cells $(60,61)$ including U937 cells $(25)$. Of interest, anti-viral effects of NO were found on viruses (56-58) which, by contrast to HIV, do not contain $\kappa \mathrm{B}$ sites. This hypothesis corroborates with Chowdhury et al. work (53), which showed the synergy between CAMP and TNF $\alpha$ in stimulating HIV-1 from chronic low-level HIV production in cells of monocyte/macrophage lineage.

Induction of nitric oxide synthase was observed in asthma (62), which corroborates with the role of NO in proviral effect of IgE-IC. NO generation by human monocytes was also observed following their activation with gpl20 (63). Bukrinsky et al. recently showed that HIV infection promoted the generation of NO in human monocytes (64), and that NO mediates neu- 
rotoxicity in HIV-infected patients $(63,64)$. While the precise mechanism(s) of NO effects remain(s) to be clarified, above data make likely the involvement of NO in HIV pathogenesis.

\section{ACKNOWLEDGMENTS}

We thank N. Paul-Eugène, J. P. Kolb, J. Wietzerbin, and $\mathrm{H}$. Valentin for their suggestions; F. Issaly for technical assistance; J. Banchereau for rIL-4 and rIL-13 gift; and M. Benhamou and $M$. Arock for reviewing our work. The contents of this publication do not necessarily reflect the views nor policies of the Department of Health and Human Services, nor does the mention of trade names, commercial products, or organizations imply endorsement by the U.S. Government.

\section{REFERENCES}

1. Gartner SP, Markovits DM, Kaplan MH, Gallo RC, Popovic M. (1986) The role of mononuclear phagocytes in HTLV-II/LAV infection. Science 233: 215-219.

2. Gendelmen HE, Orentstein JM, Martin MA, et al. (1988) Efficient isolation and propagation of human immunodeficiency virus on recombinant colony-stimulating factor-1 treated monocytes. J. Exp. Med. 167: 14281441.

3. Schuitemaker H, Kootstra NA, DeGoede REY, Dewolf F, Miedema F, Tersmette M. (1991) Monocytotropic human immunodeficiency virus type 1 (HIV-1) variants detectable at all stages of HIV-1 infection lack T-cell tropism and syncytium-inducing ability in primary T-cell culture. J. Virol. 65: 356-363.

4. Stevenson M, Stanwick TL, Dempsey DP, Lamonica CA. (1990) HIV-1 replication is controlled at the level of $\mathrm{T}$ cell activation and proviral integration. EMBO J. 9: 1551-1560.

5. Zack JA, Arrigo SJ, Weitsman SR, Go AS, Haislip A, Chen ISY. (1990) HIV-1 entry into quiescent primary lymphocytes: Molecular analysis reveals a labile, latent viral structure. Cell 61: 213-222.

6. Mikovits JA, Lohrey NC, Schulof R, Courtless J, Ruscetti FW. (1992) Activation of infectious virus from latent human immunodeficiency virus infection of monocytes in vivo. J. Clin. Invest. 90: 1486-1491.

7. Embertson J, Zupancic M, Ribas JL, et al. (1993) Massive covert infection of helper $T$ lymphocytes and macrophages by HIV dur- ing the incubation period of AIDS. Nature 362: 359-361.

8. Mikovits JA, Raziuddin R, Ribas JL, et al. (1990) Negative regulation of human immune deficiency virus replication in monocytes. Distinctions between restricted and latent expression in THP-1 cells. J. Exp. Med. 171: 1705-1720.

9. Folks TM, Justement J, Kinter A, et al. (1988) Characterization of promonocyte clone chronically infected with HIV and inducible by 13-phorbol-12-myristate acetate. J. Immunol. 140: 1117-1124.

10. Pantaleo G, Graziosi C, Demarest JF, et al. (1993) HIV infection is active and progressive in lymphoid tissue during the clinically latent stage of disease. Nature 362: 355-358.

11. Ishizaka K. (1989) Basic mechanism of IgEmediated hypersensitivity. Curr. Opin. Immunol. 4: 625-629.

12. Stevens RL, Austen F. (1989) Recent advances in the cellular and molecular biology of mast cells. Immunol. Today 10: 381-386.

13. Galli SJ. (1991) New concepts about the mast cell. N. Engl. J. Med. 328: 257-265.

14. Borish L, Mascali JJ, Rosenwasser LJ. (1991) IgE-dependent cytokine production by human peripheral blood mononuclear phagocytes. J. Immunol. 146: 63-67.

15. Capron M, Jouault T, Prin L, et al. (1986) Functional study of a monoclonal antibody to IgE Fc receptor (FceR2) of eosinophils, platelets and macrophages. J. Exp. Med. 164: 72-89.

17. Mossalayi MD, Paul-Eugène $N$, Ouaaz $F$, et al. (1994) Involvement of FceRII/CD23 and L-arginine-dependent pathway in IgE-mediated stimulation of human monocyte functions. Int. Immunol. 6: 931-934.

18. Israel-Biet D, Labrousse F, Tourani JM, Sors H, Andrieu JM, Even P. (1992) Elevation of IgE in HIV-infected subjects: A marker of poor prognosis. J. Allergy Clin. Immunol. 89: 68-75.

19. Sample S, Chernoff DN, Lenahan GA, et al. (1990) Elevated serum concentrations of IgE antibodies to environmental antigens in HIV-seropositive male homosexuals. J. Allergy Clin. Immunol. 86: 876-880.

20. Paganelli R, Scala E, Ansotegui IJ, et al. (1995) $\mathrm{CD}^{+} \mathrm{T}$ lymphocytes provide helper activity for IgE synthesis in human immunodeficiency virus-infected patients with hyper-IgE. J. Exp. Med. 181: 423-428.

21. Unanue E, Allen PM. (1987) The basis for 
the immunoregulatory role of macrophages and other accessory cells. Science 236: $551-$ 554.

22. Maurer D, Fiebiger E, Reininger $B$, et al. (1994) Expression of functional high-affinity immunoglobulin $\mathrm{E}$ receptors (FceRI) on monocytes of atopic individuals. J. Exp. Med. 179: $745-750$.

23. Delespesse G, Suter U, Mossalayi MD, et al. (1991) Expression, structure and functions of CD23 antigen. Adv. Immunol. 49: 149191.

24. Conrad DH. (1990) FceRII/CD23: The low affinity receptor for IgE. Annu. Rev. Immunol. 8: 623-645.

25. Ouaaz F, Sola B, Issaly F, et al. (1994) Growth arrest and terminal differentiation of leukemic myelomonocytic cells induced through the ligation of CD23 antigen. Blood 84: 3095-3104.

26. Paul Eugène $N$, Kolb JP, Sarfati $M$, et al. (1995) Ligation of CD23 activates soluble guanylate cyclase in human monocytes via an L-arginine-dependent mechanism. $J$. Leuk. Biol. 57: 160-167.

27. Mossalayi MD, Arock M, Delespesse G, et al. (1992) Cytokine effects of CD23 are mediated by an epitope distinct from the IgE binding site. $E M B O J$. 11: 3423-4328.

28. Bécherel PA, Mossalayi MD, Dugas B, et al. (1994) Involvement of the cAMP and nitric oxide pathway in the IgE-dependent activation of normal human keratinocytes. J. Clin. Invest. 93: 2275-2279.

29. Wang B, Rieger A, Kilgus O, et al. (1992) Epidermal Langerhans cells from normal human skin bind monomeric IgE via FceRI. $J$. Exp. Med. 175: 1353-1365.

30. Montaner LJ, Gordon S. (1995) TH2 downregulation of macrophage HIV-1 replication. Science 267: 538-539.

31. Kolb JP, Paul-Eugène N, Abadie A, Yamaoka K, Drapier JC, Dugas B. (1994) IL-4 stimulates CGMP production by IFN- $\boldsymbol{\gamma}$-activated human monocytes. Involvement of the nitric oxide synthase pathway. J. Biol. Chem. 269: 9811-9816.

32. Byrne B, Li J, Sninsky J, Poiesz BJ. (1988) Detection of HIV RNA sequences by in vitro DNA amplifications. Nucleic Acid. Res. 16: 4165-4168.

33. Poiesz BJ, Ehrlich GD, Byrne BC, Wells K, Kwok S, Sninsky J. 1990. The use of polymerase chain reaction in the detection, quantification, and characterization of hu- man retroviruses. In: de la Maza LM, Peterson EM (eds). Medical Virology. Plenum Press, New York, pp. 47-72.

34. Kwok S, Ehrich G, Poiesz B, Kalish R, Sninsky J. (1988) Enzymatic amplification of HTLV-1 viral sequences from peripheral blood mononuclear cells and infected tissues. Blood 72: 1117-1126.

35. Gendelman H, Friedman R, Joe $S$, et al. (1990) A selective defect of interferon-alpha production in human immuno-deficiency virus-infected monocytes. J. Exp. Med. 172: 1433-1442.

36. Vercelli D, Jabara HH, Lee BW, Woodland N, Geha RS, Leung DY. (1988) Human recombinant interleukin 4 induces FceRII/CD23 on normal human monocytes. J. Exp. Med. 167: 1406-1416.

37. Takizawa F, Adamczewski $M$, Kinet JP. (1992) Identification of the low affinity receptor for immunoglobulin $\mathrm{E}$ on mouse mast cells and macrophages as Fc $\gamma$ RII and Fc $\gamma$ RIII. J. Exp. Med. 176: 469-476.

38. Figeri LG, Liu FT. (1992) Surface expression of functional IgE binding protein, and an endogenous lectin, on mast cells and macrophages. J. Immunol. 148: 961-967.

39. Paul-Eugène N, Kolb JP, Abadie A, et al. (1992) Ligation of CD23 triggers cAMP generation and release of inflammatory mediators in human monocytes. J. Immunol. 149: 3066-3071.

40. Zuckerman KS, De Vries JE. (1994) Interleukin-13, an IL-4 like cytokine that acts on monocytes and $\mathrm{B}$ cells but not on $\mathrm{T}$ cells. Immunol. Today 15: 19-26.

41. Feelisch M. (1991) The biochemical pathways of nitric oxide formation from nitrovasodilators: Appropriate choice of exogenous NO donors and aspects of preparation and handling of aqueous NO solutions. J. Cardiovasc. Pharmacol. 17(Suppl 3): S25-S33.

42. Nussler AK, Billiar TR. (1993) Inflammation, immunoregulation and inducible nitric oxide synthase. J. Leuk. Biol. 54: 171-178.

43. Moncada S, Higgs A. (1993) The L-arginine nitric oxide pathway. N. Engl. J. Med. 30: 2002-2012.

44. Stuehr DJ, Griffith OW. (1992) Mammalian nitric oxide synthases. Adv. Enzymol. 65: 287-346.

45. Duvall E, Wyllie AH. (1986) Death and the cell. Immunol. Today 7: 115-119.

46. Albina JE, Cui S, Mateo RB, Reichner JS. (1993) Nitric oxide-mediated apoptosis in 
murine peritoneal macrophages. J. Immunol. 150: $5080-5085$.

47. Mossalayi MD, Arock M, Bertho JM, et al. (1990) Proliferation of early human myeloid precursors induced by interleukin-1 and recombinant soluble CD23. Blood 75: 19241927.

48. Gordon J. (1991) CD23: A novel multifunctional regulator of the immune system that bind IgE. In: Hanson LA, Shakib F (eds). Monographs in Allergy. Karger, Basel, pp. 1-208.

49. Aubry JP, Pochon S, Graber P, Jansen KU, Bonnefoy JY. (1992) CD21 is a ligand for CD23 and regulates IgE production. Nature 358: $505-508$.

50. Arock M, Le Goff L, Bécherel PA, Dugas B, Debré $P$, Mossalayi MD. (1994) Involvement of FceRII/CD23 and L-arginine dependent pathway in IgE mediated activation of human eosinophils. Biochem. Biophys. Res. Commun. 203: 265-271.

51. De Maria R, Cifone MG, Trotta $\mathrm{R}$, et al. (1994) Triggering of human monocyte activation through CD69, a member of the natural killer gene complex family of signal transducing receptors. J. Exp. Med. 180: 1999-2004.

52. Cifone MG, Festuccia $\mathrm{C}$, Cironi $\mathrm{L}$, et al. (1994) Induction of nitric oxide-synthesizing pathway in fresh and interleukin 2-cultured rat natural killer cells. Cell. Immunol. 157: 181-194.

53. Chowdhury MI, Koyonagi Y, Horiuchi S, et al. (1993) cAMP stimulates human immunodeficiency virus (HIV-1) from latently infected cells of monocyte-macrophage lineage: Synergism with TNF- $\alpha$. Virology 194: 345-349.

54. Hassan MI, Nokta MA, Pollard RB. (1993) Involvement of cAMP and protein kinase $C$ in cytomegalovirus enhancement of human immunodeficiency virus replication. Proc. Soc. Exp. Biol. Med. 204: 216-223.

55. Hofmenn B, Nishanian $P$, Nguyen T, Liu M, Fahey JL. (1993) Restoration of T-cell func- tion in HIV infection by reduction of intracellular cAMP levels with adenosine analogues. AIDS 7: 659-664.

56. Karupiah G, Xie QW, Buller R, Nathan C, Duarte C, MacMicking JD. (1993) Inhibition of viral replication by interferon- $\gamma$-induced nitric oxide synthase. Science 261: 1445-1448.

57. Croen KD. (1993) Evidence for an antiviral effect of nitric oxide. Inhibition of herpes simplex virus type 1 replication. J. Clin. Invest. 91: 2446-2452.

58. Mannick JB, Asano K, Izumi K, Kleff E, Stamler JS. (1994) Nitric oxide produced by human B lymphocytes inhibits apoptosis and Epstein-Barr virus reactivation. Cell 79: 1137-1146.

59. Schreck R, Rieber P, Bauerle PA. (1991) Reactive oxygen intermediates as apparently widely used messengers in the activation of NF- $\kappa \mathrm{B}$ transcription factor and HIV-1. EMBO J. 10: 2247-2258.

60. Chartrain NA, Geller DA, Koty PP, et al. (1994) Molecular cloning, structure, and chromosomal localization of the human inducible nitric oxide synthase gene. J. Biol. Chem. 269: 6765-6772.

61. Xie Q-W, Whisnant R, Nathan C. (1993) Promotor of the mouse gene encoding calcium-independent nitric oxide synthase confers inducibility by interferon $\gamma$ and bacterial lipopolysaccharide. J. Exp. Med. 177: 17791784.

62. Hamid A, Springall DR, Riveros-Moreno V, et al. (1993) Induction of nitric oxide synthase in asthma. Lancet 342: 1510-1513.

63. Pietraforte D, Tritarelli E, Testa U, Minetti M. (1994) gpl20 HIV envelope glycoprotein increases the production of nitric oxide in human monocyte-derived macrophages. $J$. Leuk. Biol. 55: 175-182.

64. Bukrinsky MI, Nottet HS, Schmidtmayerova $\mathrm{H}$, et al. (1995) Regulation of nitric oxide synthase activity in human immunodeficiency virus type l (HIV-l)-infected monocytes: Implications for HIV-associated neurological disease. J. Exp. Med. 181: 735-745. 